\title{
PENGARUH HARGA DAN KUALITAS TERHADAP KEPUTUSAN PEMBELIAN AYAM POTONG DI PASAR GAMALAMA
}

\author{
Hamka \\ Staf Pengajar Faperta UMMU-Ternate,e-mail: hamka_agb@yahoo.co.id
}

\begin{abstract}
ABSTRAK
Penelitian ini bertujuan mengetahui pengaruh harga dan kualitas terhadap keputusan pembelian konsumen ayam potong, dengan jumlah responden 100 konsumen yang melakukan pembelian ayam potong di pasar Gamalama. Hasil penelitian menunjukkan bahwa harga berpengaruh singnifikan terhadap keputusan pembelian dengan hasil pengujian regresi untuk variabel Harga terhadap Keputusan pembelian menunjukkan nilai thitung $=4.356$ dengan nilai signifikansi 0.000, sedangkan hasil pengujian regresi untuk variabel Kualitas produk terhadap Keputusan pembelian menunjukkan nilai thitung $=$ 2.220 dengan signifikansi 0,03. Dengan menggunakan batas signifikansi 0,05, nilai signifikansi tersebut lebih kecil dari 0,05 , maka $\mathrm{H}_{0}$ diterima. Nilai $F$ hitung sebesar 29.602 dengan signifikansi 0,000. Dengan menggunakan batas signifikansi 0,05, nilai signifikansi tersebut lebih kecil dari 0,05. Dengan arah koefisien positif, dengan demikian diperoleh bahwa hipotesis yang menyatakan bahwa harga, dan kualitas produk secara bersama-sama memiliki pengaruh yang signifikan terhadap keputusan pembelian. Koefisien determinasi (adjusted $R^{2}$ ) yang diperoleh sebesar 0,765. Hal ini berarti 76,5\% keputusan pembelian dapat dijelaskan oleh variabel harga, dan kualitas produk.
\end{abstract}

Kata Kunci: Harga, Kualitas, Keputusan Pembelian

\section{PENDAHULUAN}

1.1. Latar Belakang

Kebutuhan daging ayam ras broiler (ayam pedaging) cenderung meningkat setiap tahun. Peningkatan kebutuhan ini sejalan dengan situasi perekonomian Indonesia yang terus bertumbuh. Konsumsi ayam ras pada tahun 2013 ini mencapai 2,2 miliar ekor. Jumlah tersebut naik 15,79\% dibandingkan konsumsi ayam ras sepanjang 2012 sebanyak 1,9 juta miliar ekor. Menurut Ketua Forum Masyarakat Perunggasan Indonesia, Don P. Utoyo, konsumsi daging ayam ras meningkat lantaran pendapatan penduduk juga cenderung naik. Masyarakat yang semula tak mengkonsumsi ayam, karena pendapatan naik mampu membeli daging ayam.

Secara umum tingkat konsumsi warga Maluku Utara adalah ikan. Hal ini membuat konsumsi daging, baik daging sapi, kambing dan ayam kampung menjadi rendah, yaitu hanya sekitar 3,1 kg/kapita/tahun. Namun seiring perkembangan daerah perkotaan mulai terbiasa mengonsumsi produk unggas yang berupa daging dan telur sehingga pertumbuhan tingkat konsumsi terus mengalami peningkatan.

Penyuplai terbesar akan kebutuhan ayam potong berasal dari Manado dan Surabaya, hal ini sangat mempengaruhi tingkat harga dipasaran dan bisa berpengaruh langsung terhadap kemampuan masyarakat dalam melakukan pembelian ayam potong di pasar Gamalama. Dimana ayam broiler hidup lokal umur 35 hari dihargai Rp. 22 ribu/ekor dan ayam beku petelur afkir yang besar diterima pasar dengan harga Rp. 28 ribu/ekor.

\subsection{Rumusan Masalah}

Tingginya tingkat permintaan ayam potong di pasar Gamalama akan sangat 
berpengaruh pada penampilan harga ayam potong dan kualitas ayam potong yang di perdagangkan di pasar gamalama. Semakin tinggi harga ayam potong akan semakin mempengaruhi tingkat pembelian, demikian pula dengan kualitas ayam potong yang ditawarkan. Kecenderungan konsumen dalam melakukan keputusan pembelian ayam potong akan sangat dipengaruhi oleh faktor harga dan kaualitas, olehnya itu sejauhmana kedua faktor ini dapat memberikan pengaruh terhadap keputusan pembelian ayam potong di pasar Gamalama. Adapun rumusan masalah dari penelitian ini adalah :

1. Apakah harga berpengaruh terhadap keputusan pembelian konsumen

2. Apakah kualitas berpengaruh terhadap keputusan pembelian konsumen

\subsection{Tujuan Penelitian}

Penelitian ini bertujuan untuk mengetahui pengaruh harga dan kualitas terhadap keputusan pembelian ayam potong di pasar Gamalama

\subsection{Hipotesis}

$\mathrm{H}_{0}=$ Harga dan kualitas ayam potong berpengaruh positif terhadap keputusan pembelian konsumen

$\mathrm{H}_{1}=$ Kualitas dan kualitas ayam potong tidak berpengaruh positif terhadap keputusan pembelian konsumen

\section{METODE PENELITIAN}

\subsection{Waktu dan Lokasi Penelitian}

Lokasi yang dijadikan tempat penelitian ini adalah pasar gamalama kota ternate, pemelihan pasar Gamalama karena merupakan pasar terbesar di kota Ternate. Penentuan lokasi penelitian ini dilakukan secara purposive karena berdasarkan pertimbangan jumlah penjual dan pembeli ayam potong terbanyak berada di Kota ternate. Waktu penelitian dilakukan pada bulan Januari sampai Pebruari 2013.

\subsection{Teknik Analisis Data}

Agar suatu data yang dikumpulkan dapat bermanfaat, maka harus diolah dan di analisis terlebih dahulu, sehingga dapat dijadikan dasar pengambilan keputusan. Tujuan metode analisis data adalah untuk menginteprestasikan dan menarik kesimpulan dari sejumlah data yang terkumpul. Pengolahan data dalam penelitian ini dengan menggunakan program SPSS for Windows versi 20. Adapun metode analisis data yang digunakan adalah sebagai berikut :

\subsubsection{Analisis Regresi Linier Berganda}

Dalam analisis ini dapat dilihat bagaimana variabel bebas, yaitu Kualitas ayam (X1), dan harga penjual (X2), mempengaruhi (secara positif atau negatif) variabel terikat, yaitu keputusan pembelian ayam potong di pasar gamalama kota ternate (Y). Bentuk matematisnya secara umum adalah sebagai berikut (Santoso singgih 2001) :

$$
\mathrm{Y}=\mathbf{a}+\mathrm{b}_{1} \mathbf{X}_{1}+\mathbf{b}_{2} \mathbf{X}_{2}+\mathrm{e}
$$

di mana :

$\mathrm{Y}=$ keputusan pembelian

$\mathrm{A}=$ Konstanta dari persamaan regresi

$b_{1}=$ Koefisien regresi dari variabel $X_{1}($ kualitas )

$\mathbf{b}_{2}=$ Koefisien regresi dari variabel $X_{2}($ harga yang jual )

$\mathrm{X}_{1}=$ kualitas

$\mathrm{X}_{2}=$ harga

$\mathbf{e}=$ Eror

\subsection{Pengujian Hipotesis}

2.5.1. Uji Signifikansi Parameter Individual (Uji t)

Uji $t$ pada dasarnya menunjukkan seberapa jauh pengaruh satu variable penjelas/bebas secara individual dalam menerangkan variasi variabel terikat (Santoso singgih 2001). Pengujian ini bertujuan untuk menguji pengaruh variabel bebas (kualitas produk, harga kompetitif, dan citra merek) terhadap variabel terikat (keputusan pembelian) secara terpisah atau parsial.

Hipotesa yang akan digunakan dalam pengujian ini adalah :

- $\mathrm{H}_{0}: \beta 0=0$, Variabel-variabel bebas (kualitas dan harga terhadap konsumen) tidak mempunyai pengaruh yang signifikan terhadap variabel terikat(keputusan pembelian).

- $\mathrm{H}_{1}: \beta 1 \neq 0$, Variabel-variabel bebas (kualitas dan harga terhadap konsumen) mempunyai pengaruh yang signifikan terhadap variabel terikat (keputusan 
pembelian). Dasar pengambilan keputusan (Santoso singgih 2001) :

1. Dengan membandingkan nilai $t$ hitungnya dengan $t$ tabel.

Apabila $t$ tabel $>t$ hitung, maka $\mathrm{H}_{0}$ diterima dan $\mathrm{H}_{1}$ ditolak

Apabila $\mathrm{t}$ tabel $<\mathrm{t}$ hitung, maka $\mathrm{H}_{0}$ ditolak dan $\mathrm{H}_{1}$ diterima

2. Dengan menggunakan angka probabilitas signifikansi.

Apabila angka probabilitas signifikansi $>$ 0,05, maka $\mathrm{H}_{0}$ diterima dan $\mathrm{H}_{1}$ ditolak. Apabila angka probabilitas signifikansi < 0,05, maka $\mathrm{H}_{0}$ ditolak dan $\mathrm{H}_{1}$ diterima.

\subsubsection{Uji Signifikansi Simultan (Uji F)}

Uji $F$ bertujuan melihat apakah semua variabel bebas yang dimasukkan dalam model mempunyai pengaruh secara bersama-sama terhadap variabel terikat (Santoso singgih 2001). Dalam penelitian ini pengujian hipotesis secara simultan dimaksudkan untuk mengukur besarnya pengaruh kesadaran kualitas dan harga secara bersama-sama terhadap variabel terikatnya, yaitu keputusan pembelian. Hipotesis yang akan digunakan dalam penelitian ini adalah :

- $H_{0}: \beta 1=\beta 2=0$, Variabel-veriabel bebas (kualitas dan harga terhadap konsumen) tidak mempunyai pengaruh yang signifikan secara bersama-sama terhadap variabel terikatnya (keputusan pembelian).

- $\quad H_{1}: \beta 1=\beta 2 \neq 0$, Variabel-variabel bebas (kualitas dan harga terhadap konsumen mempunyai pengaruh yang signifikan secara bersama-sama terhadap variabel terikatnya (keputusan pembelian).

Dasar pengambilan keputusan (Santoso singgih 2001) :

1. Dengan membandingkan nilai $F$ hitung dengan $F$ tabel

Apabila $\mathrm{F}$ tabel > F hitung, maka $\mathrm{H}_{0}$ diterima dan $\mathrm{H}_{1}$ ditolak.

Apabila $\mathrm{F}$ tabel $<\mathrm{F}$ hitung, maka $\mathrm{H}_{0}$ ditolak dan $\mathrm{H}_{1}$ diterima.

2. Dengan menggunakan angka probabilitas signifikansi

Apabila probabilitas signifikansi $>0,05$, maka $\mathrm{H}_{0}$ diterima dan $\mathrm{H}_{1}$ ditolak.

Apabila probabilitas signifikansi $<0,05$, maka $\mathrm{H}_{0}$ ditolak dan $\mathrm{H}_{1}$ diterima.

\subsubsection{Uji Koefisien Determinasi $\left(R^{2}\right)$}

Koefisien determinasi $\left(R^{2}\right)$ pada intinya mengukur seberapa jauh kemampuan model (kualitas dan harga, terhadap konsumen) dalam menerangkan variasi variabel dependen/tidak bebas (Keputusan pembelian konsumen). Nilai koefisien determinasi adalah antara nol(0) dan satu (1).Nilai $R$ yang kecil berarti kemampuan variabel-variabel independen (bebas) dalam menjelaskan variasi variabel dependen amat terbatas. Nilai yang mendekati satu berarti variabel-variabel independen memberikan hampir semua informasi yang dibutuhkan untuk memprediksi variasi variabel dependen. Secara umum koefisien determinasi untuk data silang (crosssection) relatif rendah karena adanya variasi yang besar antara masing-masing pengamatan, sedangkan untuk data runtun waktu (time series) biasanya mempunyai nilai koefisien determinasi yang tinggi (Umar Husein, 2009).

\section{HASIL DAN PEMBAHASAN}

\subsection{Gambaran Umum Obyek Penelitian}

Secara umum gambaran umum responden yang melakukan pembelian ayam potong di pasar Gamalam kota Ternate disajikan pada Tabel 1.

Tabel.1 Karakteristik Responden Ayam Potong di Pasar Gamalama

\begin{tabular}{|c|c|c|c|c|c|}
\hline & Keterangan & $\mathrm{L}$ & $P$ & Jumlah & Presentase \\
\hline \multirow{4}{*}{ Usia } & $\leq 20$ tahun & 5 & 10 & 15 & $15 \%$ \\
\hline & $21-30$ tahun & 15 & 57 & 72 & $72 \%$ \\
\hline & $31-40$ tahun & 1 & 3 & 4 & $4 \%$ \\
\hline & $>40$ tahun & 3 & 6 & 9 & $9 \%$ \\
\hline \multirow{5}{*}{ Pendidikan } & SD/Sederajat & 0 & 0 & 0 & $0 \%$ \\
\hline & SMP/Sederajat & 0 & 0 & 0 & $0 \%$ \\
\hline & SMA/Sederaja & 10 & 40 & 50 & $50 \%$ \\
\hline & Akademi/D3 & 3 & 7 & 10 & $10 \%$ \\
\hline & Sarjana (\$1, S2, S3) & 11 & 29 & 40 & $40 \%$ \\
\hline \multirow{5}{*}{ Pekerjaan } & Pelajar/ mahasiswa & 7 & 4 & 11 & $11 \%$ \\
\hline & Pegawai negeri Sipil & 9 & 49 & 58 & $58 \%$ \\
\hline & Pegawai Swasta & 6 & 15 & 21 & $21 \%$ \\
\hline & Wiraswasta & 0 & 8 & 8 & $8 \%$ \\
\hline & Lainnya & 2 & 0 & 2 & $2 \%$ \\
\hline \multirow{4}{*}{$\begin{array}{l}\text { Pendapatan } \\
\text { Perbulan }\end{array}$} & $<\operatorname{Rp} 500.000,00$ & 0 & 0 & 0 & $0 \%$ \\
\hline & $\begin{array}{l}\text { Rp500.000,00 - } \\
\text { Rp1000.000,00 }\end{array}$ & 5 & 7 & 12 & $12 \%$ \\
\hline & $\begin{array}{l}\text { Rp } 1000.000,00- \\
\text { Rp2000.000,00 }\end{array}$ & 4 & 5 & 9 & $9 \%$ \\
\hline & $>\operatorname{Rp} 2000.000,00$ & 15 & 64 & 79 & $79 \%$ \\
\hline
\end{tabular}



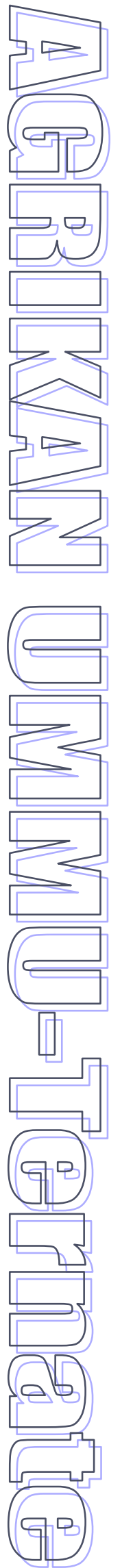

3.2. Hasil Analisis Harga dan Kulaitas terhadap Keputusan Pembelian

\subsubsection{Uji Validitas}

Uji validitas digunakan untuk mengukur sah atau tidaknya suatu kuesioner, suatu kuesioner dikatakan valid jika pertanyaan pada kuesioner mampu untuk mengungkapkan sesuatu yang akan diukur oleh kuesioner tersebut. Uji validitas dihitung dengan membandingkan nilai $r$ hitung (correlated item-total correlation) dengan nilai $\mathbf{r}$ tabel, jika $\mathbf{r}$ hitung $>$ dari $\mathbf{r}$ tabel (pada taraf signifikansi $10 \%$ ) maka pertanyaan tersebut dinyatakan valid (Umar Husein, 2009).

Pada variabel harga indikator $x 1 \quad r$ hitungnya sebesar 0,738 , indikator $x 2$ sebesar 0,746, dan indikator $x 3 \mathrm{r}$ hitungnya 0,690. Pada variabel kualitas produk indikator $x 1 \quad r$ hitungnya sebesar 0,771 indikator $\mathrm{x} 2$ sebesar 0,607 , dan indikator $x 3$ sebesar 0,622 . Pada variabel keputusan pembelian indikator $x 1 \mathrm{r}$ hitungnya sebesar 0,707 , indikator $x 2$ sebesar 0,698, dan indikator $x 3$ sebesar 0,657. Menunjukkan bahwa semua indikator yang digunakan untuk mengukur variabelvariabel yang digunakan dalam penelitian ini adalah valid karena semua indikator mempunyai $\mathrm{r}$ hitung $>$ dari $\mathrm{r}$ tabel. Pada penelitian ini $r$ tabel sebesar 0,220

\subsubsection{Uji Reliabilitas}

Uji reliabilitas adalah alat untuk mengukur suatu kuesioner yang merupakan indikator dari variabel atau konstruk. Suatu kuesioner dikatakan reliabel atau handal jika jawaban seseorang terhadap pernyataan adalah konsisten atau stabil dari waktu ke waktu. Pengujian reliabilitas dalam penelitian ini dengan menggunakan rumus alpha. Uji reliabilitas dilakukan dengan melihat hasil croanbach alpha ( $\alpha$ ) (Umar Husein, 2009).

Hasil pengujian reliabilitas, variabel harga mempunyai koefisien alpha sebesar 0,803 , variabel kualitas produk mempunyai koefisien alpha sebesar 0,864 dan variabel kualitas produk sebesar 0,802. Hasil pengujian reliabilitas pada tabel menunjukkan bahwa semua variabel dalam penelitian mempunyai koefisien alpha $(\alpha)$ yang cukup besar yaitu $>0,80$ sehingga dapat dikatakan semua konsep pengukur masing- masing variabel dari kuesioner adalah reliabel. 3.2.3. Analisis Regresi Linier

Tabel 2. Hasil Analisis Regresi Linier

\begin{tabular}{|c|c|c|c|c|c|c|}
\hline \multicolumn{7}{|c|}{ Coefficients ${ }^{a}$} \\
\hline & \multirow[t]{2}{*}{ Model } & \multicolumn{2}{|c|}{$\begin{array}{l}\text { Unstandardized } \\
\text { Coefficients }\end{array}$} & \multirow{2}{*}{$\begin{array}{c}\text { Standardized } \\
\text { Coefficients } \\
\text { Beta }\end{array}$} & \multirow[t]{2}{*}{$t$} & \multirow[t]{2}{*}{ Sig. } \\
\hline & & B & Std. Error & & & \\
\hline \multirow{3}{*}{1} & (Constant) & 2,456 & 1,148 & & 2,139 & ,035 \\
\hline & Harga &, 559 & , 128 & 448 & 4,356 &, 000 \\
\hline & Kualitas & 191 &, 087 & ,226 & 2,200 &, 030 \\
\hline
\end{tabular}

a. Dependent Variable: Pembelian

Sumber : Data primer yang diolah 2013

Persamaan regresi yang dapat dituliskan dari hasil tersebut dalam bentuk persamaan regresi bentuk standard adalah sebagai berikut :

$$
\mathrm{Y}=0,448 \mathrm{X} 1+0,226 \mathrm{X} 2
$$

Persamaan regresi tersebut dapat dejelaskan sebagai berikut :

variabel $X_{1}$ (Harga) diperoleh sebesar 0,448 dengan tanda koefisien positif. Hal ini berarti bahwa variabel Harga $\left(X_{1}\right)$ mempunyai pengaruh sebesar $44,8 \%$ terhadap variabel Keputusan Pembelian (Y) dengan asumsi semua variabel yang lain tetap. Pengaruh variabel harga merupakan pengaruh yang paling besar diantara variabel lainnya. Sehingga dapat disimpulkan bahwa harga berpengaruh positif terhadap keputusan pembelian.

$\mathrm{X}_{2}$ (Kualitas Produk) diperoleh sebesar 0,226 dengan tanda koefisien positif. Hal ini berarti bahwa variabel Kualitas Produk $\left(\mathrm{X}_{2}\right)$ mempunyai pengaruh sebesar $22,6 \%$ terhadap variabel Keputusan Pembelian (Y) dengan asumsi semua variabel yang lain tetap. Pengaruh variabel kualitas produk merupakan pengaruh yang paling kecil diantara variabel lainnya. Sehingga dapat disimpulkan bahwa kualitas produk berpengaruh positif terhadap keputusan pembelian.

\subsubsection{Pengujian Parsial (uji t)}

Hasil pengujian regresi untuk variabel Harga terhadap Keputusan pembelian menunjukkan nilai $t$ hitung $=4.356$ dengan nilai signifikansi 0,000 . Dengan menggunakan batas signifikansi 0,05 , nilai signifikansi tersebut lebih kecil dari 0,05, maka hipotesis 1 diterima.

Hasil pengujian regresi untuk variabel Kualitas produk terhadap 
Keputusan pembelian menunjukkan nilai $t$ hitung $=2.220$ dengan signifikansi 0,03 . Dengan menggunakan batas signifikansi 0,05, nilai signifikansi tersebut lebih kecil dari 0,05, maka Hipotesis 2 diterima.

\subsubsection{Pengujian Simultan (uji F)}

Tabel 4. Hasil uji-F

\begin{tabular}{|c|c|c|c|c|c|c|}
\hline & Model & Sum of Squares & df & Mean Square & $\mathrm{F}$ & Sig. \\
\hline \multirow{3}{*}{1} & Regression & 141,522 & 2 & 70,761 & 29,602 &, $000^{4}$ \\
\hline & Residual & 231,868 & 97 & 2,390 & & \\
\hline & Total & 373,390 & 99 & & & \\
\hline
\end{tabular}

b. Predictors: (Constant), Kualitas, Harga

Hasil pengujian diperoleh nilai $F$ hitung sebesar 29.602 dengan signifikansi 0,000. Dengan menggunakan batas signifikansi 0,05 , nilai signifikansi tersebut lebih kecil dari 0,05. Dengan arah koefisien positif, dengan demikian diperoleh bahwa hipotesis yang menyatakan bahwa harga, dan kualitas produk secara bersama-sama memiliki pengaruh yang signifikan terhadap keputusan pembelian.

3.2.6. Koefisien Determinasi $\left(R^{2}\right)$

Tabel 5. Koefisien Determinasi

\begin{tabular}{|c|c|c|c|c|}
\multicolumn{5}{|c|}{ Model Summary } \\
\hline Model & $\mathrm{R}$ & $\mathrm{R}$ Square & $\begin{array}{c}\text { Adjusted R } \\
\text { Square }\end{array}$ & $\begin{array}{c}\text { Std. Error of the } \\
\text { Estimate }\end{array}$ \\
\hline 1 & $.879^{\mathrm{a}}$ & .774 & .765 & 1.04177 \\
\hline a. Predictors: (Constant), Kualitas, Harga & & \\
\hline
\end{tabular}

Hasil perhitungan regresi dapat diketahui bahwa koefisien determinasi (adjusted $R^{2}$ ) yang diperoleh sebesar 0,765. Hal ini berarti $76,5 \%$ keputusan pembelian dapat dijelaskan oleh variabel harga, dan kualitas produk, sedangkan sisanya yaitu $(100 \%-76,5 \%=23,5 \%)$ dapat dijelaskan oleh variabel- variabel lainnya yang tidak diteliti dalam penelitian ini.

\subsection{Pembahasan}

Harga Ayam potong dan Kualitas Ayam potong memberika pengaruh yang besar terhadap keputusan pembelian. Konsumen sangat memperhatikan kedua variabel ini, dimana jika harga semakin tinggi maka konsumen bisa tidak melakukan pembelian, dan jika kualitas tidak sesuai dengan besarnya harga yang dibayarkan oleh konsumen maka konsumen tidak akan melakukan pembelian.

Diantara kedua variabel ini, harga ayam potong memiliki pengaruh yang lebih dominan dibandingkan dengan kualitas. Hal ini berarti keputusan pembelian ayam potong masih cukup kuat dipengaruhi oleh harga jika dibandingkan dengan kualitas. Pada aspek kualitas konsumen masih memiliki alternatif jika harga ayam melonjak tajam, dimana konsumsi ayam akan dialihkan ke konsumsi ikan.

Dengan demikian maka pedagang akan sangat hati-hati dalam penentuan harga ayam potong dan kualitas ayam potong yang dipasarkan. Semakin konsumen menganggap harga yang ditawarkan terlalu mahal, maka konsumen akan mengalihkan pembelian pada kebutuhan lainnya. Demikian juga dengan kualitas, jika konsumen merasa kualitas ayam potong tidak sesuai dengan harapan, maka konsumen akan mengalihkan pembelian pada bahan pangan lainnya.

\section{KESIMPULAN}

Berdasarkan hasil penelitian, maka dapat disimpulkan bahwa :

1. Harga memberikan pengaruh yang signifikan terhadap keputusan pembelian konsumen terhadap ayam potong di pasar Gamalama. Semakin cocok harga yang ditawarkan oleh produsen terhadap konsumen, maka semakin kuat keputusan pembelian yang akan dilakukan oleh konsumen terhadap ayam potong.

2. Kualitas memberikan pengaruh yang signifikan terhadap keputusan pembelian, dimana konsumen akan melakukan pembelian jika kualitas ayam potong yang ditawarkan sesuai dengan keinginan konsumen

\section{DAFTAR PUSTAKA}

Ghozali, Imam. 2009. Aplikasi Analisis Multivariate dengan Program SPSS. Semarang: Badan Penerbit Universitas Diponegoro

Kazmier, Leonard. J. 2004. Statistik Untuk Bisnis. Jakarta: Penerbit Erlangga

Kuncoro, Mudrajad. 2001. Metode Kualitatif (Teori dan Aplikasi Untuk Bisnis dan Ekonomi). 
Yogyakarta: Unit Penerbit dan Percetakan AMP YKPN

Nabhan, F dan Enlik K. 2005. “Faktor-Faktor yang Berpengaruh Terhadap Keputusan Konsumen dalam Melakukan Pembelian pada Rumah Makan di Kota Batu". Jurnal Ekonomi dan Manajemen, Vol. 6, No. 3, Hlm. 425-430.

Narimawati, Umi. 2008. Teknik-Teknik Analisis Multivariant Untuk Riset Ekonomi. Yogyakarta: Graha Ilmu

Santoso, Singgih. 2001. SPSS Versi 10 (Mengolah Data Statistik Secara Profesional). Jakarta: Elex Media Komputindo

Setiawati, Bekti. 2006. “Pengaruh Kualitas Produk dan Promosi Terhadap Keputusan Pembelian Kerupuk Rambak "Dwijoyo" di Desa Perangguhan Kecamatan Pegadan Kabupaten Kendal". Skripsi S1 Jurusan Manajemen, Universitas Negeri Semarang.

Stanton, William J. dan Y. Lamarto. 2004. Prinsip Pemasaran. Jakarta: Penerbit Erlangga

Sumarwan, Ujang. 2004. Perilaku Konsumen (Teori dan Penerapannya dalam Pemasaran). Bogor: Penerbit Ghalia Indonesia

Umar, Husein. 2009. Riset Pemasaran dan Perilaku Konsumen. Jakarta: PT Gramedia Pustaka Utama

Windoyo, Riky F. 2009. “Analisis Pengaruh Kualitas Pelayanan, Kualitas Produk, Persepsi Harga dan Lokasi Terhadap Kepuasan Konsumen (Studi Kasus pada Waroeng Steak \& Shake Semarang)". Skripsi S1, Universitas Diponegoro. 